\section{Guys Like Gauguin: A Legacy of Colonialism}

\section{Emma Pilker}

Senior, Art History

\section{Introduction}

Paul Gauguin's body of work lives at the intersection of orientalist and primitivist myth. He had a conscious hand in creating the mythology surrounding his work; his imagination was the source for the fiction of both his own life events and depictions of nonWestern cultures. Separating who Gauguin is as an artist from who Gauguin was as a man proves a difficult task. A large body of work exists dedicated to documenting and understanding Gauguin's biography, investigating evidence that may or may not shed light on the truest or most honest version of Paul Gauguin. ${ }^{1}$ Despite the unknowability of who any person truly is, presenting itself as an obstacle in this process, scholars throughout the years have scoured his biographical information, life events, and letters for clarity. While this may add to the discourse surrounding how Gauguin's life affected his work, it is more illuminating to look at Gauguin's work for evidence of how he conceptualized himself in relation to others.

Self-image was a major component of Gauguin's creative endeavor. His mythology or, to use a term coined by Roland Barthes, "mythic speech," was self-conscious and manifested in his various creations - works of art, works of fiction, and letters. ${ }^{2}$ His final self-

${ }^{1}$ Suzanne Greub, Gauguin: Polynesia (Munich: Hirmer Publishers, 2012), 346.

2 Abigail Solomon-Godeau, "Going Native: Paul Gauguin and the Invention of Primitivist Modernism," in portrait exposes the un-remarkability of the façade that he relied on for his acclaim. The way Gauguin objectified non-white and primarily female bodies in his paintings, which was a carefully crafted part of this façade, paired with his overwhelming fame and status in Western culture, contributes to a constant recolonization that occurs in the art world and permeates outward through academia, institutions, and cultural consumption. Preserving and honoring Gauguin, and artists similar to himself, while largely ignoring artists from areas that he appropriated contributes to the looming institution of French colonialism and creates an art world that privileges whiteness and Eurocentric narratives. The structure of such an art world is hostile to individuals who feel non-European narratives are worthy of inquiry and study.

\section{Gauguin: The Man}

Gauguin's life is fascinating and enthralling to many scholars and audiences. The incongruences between Gauguin's selfcrafted, outward facing image and facts that oppose his narrative are worth examination. When investigating these incongruences, one finds that study regarding the effects of Gauguin's life on the individuals and groups he marginalized are overwhelmingly understudied. ${ }^{3}$ This points to a larger problem with Gauguin's presence in the Western art historical narrative. The idolization of Gauguin serves as just one of several functions that keep art history a predominantly white field that prioritizes white, male, Eurocentric art.

\section{Gauguin: The Artist}

The Expanding Discourse: Feminism and Art History, ed. Norma Broude et al. (Boulder: Westview Press, 1992), 315.

${ }^{3}$ Greub, Gauguin, 324. 
Gauguin's formal qualities from his early work conformed to the traditional bounds of Impressionism. ${ }^{4}$ He was able to transform from below average into "The Father of Modernism" when he underwent a drastic change in subject matter. ${ }^{5}$ With this reorientation toward exoticism he drew widespread fascination with his work. ${ }^{6}$ It begs the question of if Gauguin achieved his fame through his revolution of form or more through the fascination he and his audience had with the subject matter. Perhaps his boldness with color and exploration with planar figures would have been received differently had Gauguin not chosen to create images of brown-skinned, dark-haired women in a paradisiacal landscape so starkly different from anything found on the continent of Europe. Exoticism helped him find success in his field regardless. Gauguin did not make any sales to major art world players until 1888, after his first trip to Martinique. The trip to Martinique led to Theo van Gogh, and probably his brother, visiting Gauguin to purchase the Martinique works. ${ }^{7}$ Amidst the same period is when Gauguin said that the best way to receive acclaim in the art world is to travel to and depict the "other.", As he did so, Gauguin embarked on his own quest to find himself in what he deemed "the savage."

His quest for a "savage" life may have been partly motivated by less offensive desires.

\footnotetext{
${ }^{4}$ Richard Brettell et al., The Art of Paul Gauguin (Washington: National Gallery of Art, 1988), 11.

5 Solomon-Godeau, "Going Native," 316.

${ }^{6}$ Amy Dickson, "Gauguin: A Very British Reception," in Gauguin: Maker of Myth, ed. Belinda Thomson (Princeton: Princeton University Press, 2010), 314.

${ }^{7}$ Brettell et al., Paul Gauguin, 12.

${ }^{8}$ Daniel Wildenstein, Gauguin: A Savage in the Making, Catalogue Raisonné of the Paintings (1873-1888) (Torino: Skira Editore S.P.A, 2002), XIII.

${ }^{9}$ Ibid, 23.
}

In escaping a rapidly industrializing France, Gauguin found a life that was well suited for many artists that included a low cost of living, close interaction with nature, and freedom from familial or financial duties. ${ }^{10}$ While there may have been authenticity in this part of his desire to migrate to Polynesia, his depictions of Polynesian subjects were entirely of his own mind - there are many documented cases of Gauguin depicting cultural and ecological inaccuracies. ${ }^{11}$ Some of these inaccuracies include that many of his Tahitian titles for his work are untranslatable, which is of no surprise when considering the many times Gauguin tried to learn the language and failed, and the well-documented lack of interactions Gauguin had with indigenous populations, despite living there for years. ${ }^{12}$

\section{Self-Portrait}

Jean Dolent claimed there were two men in Gauguin who opposed each other: who he was as a man and who he was as an artist, possibly suggesting the artificiality behind Gauguin's artist persona. ${ }^{13}$ Gauguin's selfproclaimed "savagery" and his desire to fit in with various non-Western natives was his most precious aspect of his performative identity. He claimed multiple times to be of "mixed-race" descent and to have "Incan" blood. ${ }^{14} \mathrm{His}$ attempt to connect with this part of himself can be seen in his many self-portraits, where he tried to paint himself in a grotesque, ghastly way; he portrayed his face as shockingly

\footnotetext{
10 James F. Knapp, "Primitivism and Empire: John Synge and Paul Gauguin," Comparative Literature 41, no. 1 (Winter 1989): 56, doi: 10.2307/1770679.

11 Solomon-Godeau, "Going Native," 320.

12 Brettell et al., Paul Gauguin, XXVI. 13

Ibid.

14 Ibid.
} 
angular with what he called his "evil eye" - a cold, calculating stare; an impenetrable mask of insincerity. His claims to Incan heritage or any type of non-whiteness have been debunked by family historiographies. ${ }^{1516}$

Gauguin's self-mythology is

inextricably bound to a desire to offend - to be a cultural transgressor, to shock, and to disgust. The key to Gauguin's originality lay in his need to create a visual extreme, to a degree of hostility. ${ }^{17}$ This is why his self-portraits, for a long time, were so angry, provocative, and almost defiantly confrontational. ${ }^{18}$ One of the only exceptions to this rule can be found in his final self-portrait, which is evidential of a Gauguin who both evolved and descended into a final authenticity. This last self-portrait, painted in his final year, is a plea before death - the honest qualities here reveal the shallow, theatrical, over-exaggerated artificiality of his other works. This veneer hinged not on location but on an opportunist, colonial willingness to equate a non-white group as outside the realm of palatability and for the edgy consumption of Europeans who lacked an indigenous cultural heritage. ${ }^{19}$

This final self-portrait was made in 1903. Painted on Atuono in French Polynesia, this portrait was finished before he died in May of the same year, in the same place. Here, he is depicted from a straightforward angle. His clothes and hair have been called austere; he

${ }^{15}$ Ibid.

${ }^{16}$ Ibid.

${ }^{17} \mathrm{Ibid}, \mathrm{XXIII}$.

${ }^{18} \mathrm{Ibid}$.

19 Jean-François Staszak. "L'exote, l'oviri, l'exilé: Les singulières identités géographiques de Paul Gauguin / The Exote, the Oviri and the Exiled: Gauguin's Singular Geographical Identities," Annales De Géographie, 113 no. 638/639 (2004): 370, http://www.jstor.org/stable/23456689. wears a small pair of spectacles that connote a thoughtful, docile old man. It is as if "there is no one left to convince and only death to confront."20,21 The noise of Gauguin's mythic speech falls silent. Provocation and vanity evaporate from their shallow depths. The portrait is devoid of theatre. ${ }^{22}$ He wears white - in what possibly could be a hospital gown-looking studious with an intense gaze. Gauguin was fabricating his memoirs during this same period - the portrait could be the visual manifestation of a final, personal encounter with his real self. ${ }^{23}$ The absence of fantasy and primitivism looms large, considering that Gauguin built his mythology, his career, and his acclaim, on the fantastic and the primitive. One cannot help but notice that even his nose is smaller. It is no longer jutting out his face like it is in his Self Portrait dedicated to Carrière, Bonjour Monsieur Gauguin, Christ in the Garden of Olives, or his Self Portrait from 1889.

Gauguin did not create any self-portraits during his first trip to Tahiti in 1891-3. ${ }^{24}$ Perhaps he realized how profitable this truly "primitive" subject matter could be. After this first trip, his self-portraits evolved, as if interactions amongst the "savages" further elevated his own self-image. His self-portraits display Gauguin, confident man of the world, and Gauguin, the world traveler, in portraits such as his 1893 Self Portrait With Palette and Self-Portrait with Manao tupapau. He even goes on to set his own features aside a wooden

\footnotetext{
${ }^{20}$ Brettell et al., Paul Gauguin, XXVI.

21 Ibid.

22 Belinda Thomson, "Identity and Self Mythology" in Gauguin: Maker of Myth, ed. Belinda Thomson (Princeton: Princeton University Press, 2010), 73.

23 Ibid.

24 Ibid.
} 
idol with a form that he stole from Oceania in Portrait of the Artist with Idol. ${ }^{25}$ Later in his progression through self-portraiture, Gauguin shows a propensity for the image of the devila horned figure that surfaces repeatedly and which Gauguin, no doubt, related to his own self, or at least, how others saw him. ${ }^{26}$ Gauguin reveled in his status as an outsider, which manifested, visually, in many different forms, sometimes otherworldly and sometimes of this world. For Gauguin, Tahiti might as well have been a land designed for and like the devil - a motif he referenced frequently. Though Tahiti is real and the devil is a manifestation of religion, both were blank canvases for Gauguin on which to project his own carefully constructed identity; both were just as real and as human to him.

\section{How Self Portraits Fit into the Dichotomy Between Man and Artist}

There have been meticulous efforts in the West to create a boundary between Gauguin the artist and Gauguin the man. A belief in the inherent value of Gauguin's work and his status as the, or a, Father of Modernism gives Westerners the urge to celebrate his work while halting the conversation about the questionable aspects of Gauguin's legacy. In the major 1988 exhibition, The Art of Paul Gauguin, the curators lend a Freudian hand to the discussion of his self-portraits, noting that he cleverly treated even his own personal appearance as a disguise. ${ }^{27}$ Séguin said that Gauguin invented everything, from his method of canvas preparation to his way of dressing. Each of these aspects, Séguin said, was part of his disguise, which made up his persona. This

\footnotetext{
25 Ibid, 74.

26 Ibid.

${ }^{27}$ Brettell et al., Paul Gauguin, VIII.
}

persona allowed Gauguin to distance himself from Impressionism. ${ }^{28}$

Gauguin often called his own face the face of a "savage." ${ }^{29}$ His self-portraits were very much a part of his mythology. These are inextricably intertwined: his mythology and his identity as "savage." These two constructs evolve as Gauguin moves through life and further refines his own definition of "savage." After painting in Brittany, which was Gauguin's first artistic encounter with the "other," Gauguin painted Les Misérables, wherein he wears the mark of a Breton fisherman - a blue jersey — which Gauguin associated with the primitive life in Brittany that he was so fascinated with. ${ }^{30}{ }^{31}$

\section{Cultural Appropriation}

The Western narrative is one that so critically hinges on the lone, unique, genius, white male trope - he who travels alone, who isolates himself for his art, and who brings a gift to society through his romantic and exhilarating journeys that border on martyrdom. Gauguin is a poster-child for this narrative. Both his ability to be successful doing what he did and his looming legacy were made possible by the structure of white supremacist colonialism, and he perpetuated white supremacy by appropriating, subjugating, and appropriating a society. The urge for white people in a world dominated by white supremacy to take from people and cultures they find savage, to chip away at their customs, and to take bits and pieces of cultural heritage where and when they please has been and is unavoidable. In his Atlantic article "The Case

\footnotetext{
28 Ibid, XVIII.

${ }^{29}$ Wildenstein, Gauguin, XIV.

30 Knapp, "Primitivism and Empire," 34.

31 Brettell et al., Paul Gauguin, XIX.
} 
for Reparations," Ta-Nehisi Coates reminds his readers: "When we think of white supremacy, we picture Colored Only signs, but we should picture pirate flags. $" 32$ The very structure of the world today is based on the idea that white people may travel where they please and own whatever it is that they find, without regard for the others. It was and is organized in a sinister, deliberate way. It is part of what has been called the profound offense of cultural appropriation. $^{33}$

Dr. James Young explores what, exactly, makes cultural appropriation wrong, and deduces that offending someone is morally wrong because it strikes at a person's sense of self and personal philosophy. ${ }^{34} \mathrm{He}$ outlines the three types of appropriation that are gross offenses: subject appropriation, when an outsider represents members or aspects of another culture, content appropriation, when an outsider uses another culture in the production of his or her own work, and object appropriation, when an outsider possesses a tangible object that is taken from insiders and transferred to the possession of outsiders. ${ }^{35}$ Gauguin was notorious for all three of these but especially for the first two kinds. In fact, he staked his career on the first type and relied heavily on the second one for content. For subject appropriation, which Gauguin did at a prolific rate, Young suggests that the depiction of a culture by an outsider "exposes the culture

\footnotetext{
32 Ta-Nehisi Coates, "The Case for Reparations," The Atlantic, June 2014,

https:/www.theatlantic.com/magazine/archive/2014/06/t he-case-for-reparations/361631/.

33 James O. Young, "Profound Offense and Cultural Appropriation," The Journal of Aesthetics and Art Criticism 63, no. 2 (Spring 2005): 135, http://www.jstor.org/stable/3700467.

34 Ibid.

${ }^{35}$ Ibid, 136.
}

to ridicule" by perpetuating falsehoods about the culture. ${ }^{36}$ When examining this paradigm through an insider versus outsider lens, it becomes clear that Gauguin, who is on the outside, has created a similar situation in Polynesia by being the Pacific's primary informant to the "West." The outsider can say literally anything at all and the other outsiders would have only that outsider's experiences to go off of - thus starting and perpetuating a cycle of inaccurate observations, offensive misrepresentations, and stereotypes, which combine to relegate the offended group to a vulnerable place of disenfranchisement that opens them up to more than just misrepresentations, and, in fact, subjects them to institutional violence, exploitation, militarization, oppressive economic systems, widespread dehumanization, and other effects of the calcified legacy of white supremacy. This is precisely what Gauguin does through his artworks, fiction, and letters. $\div$ he says literally anything at all. The tales the Gauguin spins somehow become the authority on Polynesian art. White or Western scholars can hardly discuss Polynesian art without relating it to the context of Gauguin.

Colonization exploits people and ruins land. By the time Gauguin got to Tahiti, two thirds of their population had been wiped out. ${ }^{37}$ The greater context of being a French person visiting a French colony places Gauguin within the narrative of French imperialism. The legacy of white militarization of the Pacific Islands is lengthy and complex. It is one that is still playing out. Only as recently as the 1980's, French nuclear testing in Mururoa and Fangataufa began, which culminated in riots in

\footnotetext{
${ }^{36}$ Young, "Profound Offense," 137.

37 Greub, Gauguin, 260.
} 
downtown Papeete in $1995 .{ }^{38}$ This gave way to a response piece called D'Apres Paul Gauguin by Tahitian artist Andre Marere. ${ }^{39}$ Marere is one of many Polynesian artists who relate Gauguin to French imperialism and hold him up to close scrutiny from a personal, moral standpoint. The militarization of Polynesia at the end of the 20th century and Gauguin are connected seamlessly through the philosophy of his work: "The land, seen by many as Papatuanuku, the Earth Mother, a nurturer and provider, is attached and devastated by French imperialism, just as the women of Tahiti have been exploited by centuries of Eurocentric eroticized and exoticized representations and sensibilities."

\section{Integrating Reception Theory}

The reception of Gauguin by a number of Polynesian artists has been one that acknowledges his legacy and how he represents, in one person, the archetypal colonial Orientalist. He is every component of the colonialist; he is celebrated for his bohemian, traveler-adventure lifestyle, the romanticism of his quest for personal enlightenment, and, that his status as oppressor and sexual predator is often minimized, those parts of him are celebrated too. ${ }^{41}$ Samoan poet Selina Tusitala Marsh articulates this sentiment well:

"thanks Bougainville

for desiring 'em young

so guys like Gauguin could dream

and dream

then take his syphilitic body

downstream to the tropics

${ }^{38} \mathrm{Ibid}, 348$.

${ }^{39}$ Ibid.

${ }^{40}$ Ibid.

${ }^{41}$ Ibid. to test his artistic hypothesis

bout how the uncivilised

ripen like pawpaw and are best slightly raw delectably firm

dangling like golden prepubescent buds

seeding nymphomania for guys like

Gauguin."42

The responses across the Pacific run in a similar vein. Free Polynesia, an exhibition in Auckland featured a work made especially for the show by the Maori Samoan artist Lily Laita called Paragon of French Syphilization.

Making a clear correlation between the legacy of Gauguin and nuclear testing as part of a continuum of French Pacific colonialism, this installation piece combined formal elements of the French flag and a woman's torso painted in Gauguin's signature style. The combination of island and body is palpable. ${ }^{43}$ Polynesian artist Tyla Vaeau's works Tehamana Has Many Ancestors and When Will You Marry are Gauguin style paintings with photos of Vaeau's friends and family members, who are Polynesian women, making exaggerated or silly faces superimposed onto them. They are, importantly, "a reminder that, for the most part, Gauguin's Polynesian subjects were real girls who sat for him." The images pose questions about the relationship of the various sitters and the artist. ${ }^{44}$ How might they have felt? What were the dynamics of these engagements? Unlike the vast majority of scholarly responses that do not pay any real attention to these women, for artists like Vaeau, it plays a crucial role in her critique of and response to Gauguin.

\footnotetext{
42 Selina Tusitala Marsh, "Guys Like Gauguin," from Fast Talking PI (2009).

43 Greub, Gauguin, 348.

44 Ibid.
} 
Why do contemporary responses matter? Because they offer another side to the narrative of Gauguin and, in effect, they undo some of his damage in giving people of Polynesia the agency to tell non-Polynesian people what it means to be Polynesian. In confronting Gauguin through their art, they are able to reclaim their culture, to which they and they alone are entitled. They fill in the gaps where scholarship falls short, because they, as artists and as insiders to the culture, are able to insert their feelings. They make connections that others cannot - connections that are important. By ignoring these responses, the Pacific is re-colonized. In the 1990's a new wave of Polynesian contemporaries began to lift up their voices - only to be silenced. Every time Gauguin is spoken about without an utterance regarding his role in colonialism, every time the formal qualities of his works are discussed without any humanity given to his subjects, the shackles of colonialism in the Pacific are tightened.

\section{Feminist and Post-Colonial Interpretations}

Gauguin was a predator toward not only women, but a specific type of woman-women who were the racial "other." 45 Gauguin did not fetishize white women the way he fetishized non-white women, he did not violate them the way he violated and objected non-white bodies. Gauguin's patriarchal and colonialist imagination was shaped by his time and continues to thrive in a time that still worships and admires that man who can be both patriarchal and a colonizer.

The rape of Gauguin's "vahines" is a subject that does not rival Gauguin's value. It is this way even though he wrote in the margins

45 Solomon-Godeau, “Going Native," 314. of Noa Noa: "I saw plenty of calm-eyed women. I wanted them to be willing to be taken without a word, brutally. In a way [it was a] longing to rape." 46 Goodeau points out that while modernists were often proud to be sexual outlaws of a type, that this paradigm is built on historic contexts that allowed such violence to be perpetuated against women who are also primitive. ${ }^{47}$ This tendency can be directly linked to the fetish-driven violence inflicted onte women of color all around the world.

Formally speaking, the feminist would look at Gauguin's 1903 self-portrait and be suddenly aware that Gauguin was able to capture to the persona and the nuance of a person. It is present in this strikingly honest portrayal of himself, but also in all of his portrayals of himself and of his white male friends - they are dimensional, mysterious, enigmatic, sometimes bizarrely portrayed men. Why, then, for Polynesian women was Gauguin only able to portray zombie bodies? They are stoic and wooden, which calls to mind the mere fantasy they are meant to stand in for. ${ }^{48}$ His interactions with and depictions of the women of Tahiti were an attempt at misogynist and colonial self-indulgence, a projection born of patriarchy with white men at the top, which is a serious matter, as this is part of a pattern that actively oppresses women of color. ${ }^{49}$

\section{Social Value}

There is often an overarching argument that offensive people can be excused because what they produce is of high social value; examples include Woody Allen, who married his partner's adopted daughter, a woman of

\footnotetext{
${ }^{46}$ Ibid, 324.

47 Ibid.

${ }^{48}$ Ibid, 328.

${ }^{49}$ Ibid, 324.
} 
color who was severely abused in her childhood to the point of brain damage. The social value of Gauguin's work has been solidified. One could argue that this social value is apparent. He has codified a Western representation of the Pacific. His images are widespread, recognizable, and taught in nearly every Western art history survey. However, the social value of his legacy of also currency in the daily transaction between oppressor and oppressed; this social value does not diminish his role in colonialism. Perhaps the harm that Gauguin's legacy inflicts onto others is worth considering further and more critically.

\section{Bibliography}

Brettell, Richard, Françoise Cachin, Claire Frèches-Thory, Charles F. Stuckey, and Peter Zegers. The Art of Paul Gauguin. Washington: National Gallery of Art, 1988.

Coates, Ta-Nehisi. "The Case for Reparations." The Atlantic, June 2014. https://www.theatlantic.com/magazine/archive/ 2014/06/the-case-for-reparations/361631/.

Dagen, Philippe. "Gauguin's Politics.” In Gauguin: Maker of Myth, edited by Belinda Thomson, 40-47. Princeton: Princeton University Press, 2010.

Dickson, Amy. "Gauguin: A Very British Reception." In Gauguin: Maker of Myth, edited by Belinda Thomson, 64-69. Princeton: Princeton University Press, 2010.

Garb, Tamar. "Gauguin and the Opacity of the Other: The Case of Martinique." In Gauguin: Maker of Myth, edited by Belinda Thomson, 24-31. Princeton: Princeton University Press, 2010.
Goddard, Linda. “'Following the Moon': Gauguin's Writing and the Myth of the 'Primitive'." In Gauguin: Maker of Myth, edited by Belinda Thomson, 32-39. Princeton: Princeton University Press, 2010.

Greub, Suzanne. Gauguin: Polynesia. Munich: Hirmer Publishers, 2012.

Knapp, James F. "Primitivism and Empire: John Synge and Paul Gauguin." Comparative Literature 41, no. 1 (Winter 1989): 53-68. doi: $10.2307 / 1770679$.

Solomon-Godeau, Abigail. "Going Native: Paul Gauguin and the Invention of Primitivist Modernism." In The Expanding Discourse: Feminism and Art History, edited by Norma Broude and Mary D. Garrard, 314- 331. Boulder: Westview Press, 1992.

Staszak, Jean-François. "L'exote, l'oviri, l'exilé: Les singulières identités géographiques de Paul Gauguin / The Exote, the Oviri and the Exiled: Gauguin's Singular Geographical Identities." Annales De Géographie, 113 no. 638/639 (2004): 363-384. http://www.jstor.org/stable/23456689.

Thomson, Belinda. "Identity and Self Mythology." In Gauguin: Maker of Myth, edited by Belinda Thomson, 70-92. Princeton: Princeton University Press, 2010.

Thomson, Belinda. "Paul Gauguin: Navigating the Myth." In Gauguin: Maker of Myth, edited by Belinda Thomson, 10-23. Princeton: Princeton University Press, 2010.

Thomson, Belinda. "Teller of Tales." In Gauguin: Maker of Myth, edited by Belinda Thomson, 190-203. Princeton: Princeton University Press, 2010.

Tusitala, Selina. “Guys Like Gauguin.” In: Fast Talking PI. 2009. 
Wildenstein, Daniel. Gauguin: A Savage in the Making, Catalogue Raisonné of the Paintings (1873-1888). Torino: Skira Editore S.P.A, 2002.

Young, James O. "Profound Offense and Cultural Appropriation." The Journal of Aesthetics and Art Criticism 63, no. 2 (Spring 2005): 135-146.

http://www.jstor.org/stable/3700467. 